\title{
NON-FINANCIAL REPORTING OF LARGE UNDERTAKINGS IN THE CZECH REPUBLIC
}

\author{
IVA HASÍKOVÁ, RADKA NESVADBOVÁ, KATEŘINA BATELKOVÁ, \\ MILENA OTAVOVÁ, JANA GLÁSEROVÁ
}

${ }^{1}$ Mendel University in Brno, Faculty of Business and Economics, Brno, Czech Republic

\begin{abstract}
Directive 2014/95/EU was implemented in Czech accounting legislation with effect from 2017. It introduced an obligation for certain undertakings to report non-financial information. The paper deals with non-financial information and its reporting by large undertakings in the Czech Republic. It defines the theoretical basis of non-financial reporting and the degree of implementation of the Directive in Czech accounting legislation. The analytical part of the paper is based on the content analysis of annual reports or separate non-financial reports of the large undertakings, for which the reporting of non-financial information is mandatory, for the years 2016, 2017, and 2018 according to the GRI methodological procedure. On the basis of the comparison of annual reports in the years analysed, the impacts of the implementation of the Directive on the reporting of nonfinancial information and the approach of the undertakings concerned to its reporting are identified. Furthermore, the relationship between the size of the undertaking within the category of large undertakings with more than 500 employees and the reporting of nonfinancial information for 2018 is examined. In total, annual reports or specialized nonfinancial reports of 568 undertakings were studied.

Purpose: One of the aims of this paper is to answer the question of whether there has been a qualitative or quantitative change in the non-financial reporting of enterprises for which disclosure is mandatory. It also deals with the answer to the research question whether the size of a company in the category of large companies affects the willingness of companies to report non-financial information.

Methodology: A comparison of reported non-financial information was made for 2016 and subsequently for 2017 and 2018, i.e., for the years before and after the implementation of the Directive. On the basis of comparison, it was examined whether the legislative measure adopted contributed to higher quality non-financial reporting. The total number of undertakings is 15. The content analysis of a total of 45 reports for the years 2016, 2017 and 2018, which was performed manually, enabled to assess the approach of the undertakings studied to non-financial reporting. Subsequently, the data were processed using MS Excel. The research was based on indicators which included economic, environmental, labour law, human rights and social areas. Specific non-financial indicators were based on the Global Reporting Initiative (GRI) methodology.

Findings: It was found that more than half of the undertakings surveyed are not interested in full reporting of non-financial information and at the same time it was statistically proven that there is a significant relationship between willingness to report non-financial information and the size of the undertaking with respect to turnover, assets, and number of employees..
\end{abstract}

Key words: annual report, Directive 2014/95/EU, large undertaking, non-financial information 


\section{Introduction}

At present, in addition to financial reporting of undertakings, non-financial reporting is also becoming increasingly important. Non-financial information is the information about the undertaking's activities, especially in social, environmental and ethical fields Pramanik et al. (2008). This interconnects these activities with the economic activity of the undertaking. Information about culture of the undertaking, care for employees and customers or the environment says a lot about the undertaking and its future development as significantly as, for example, information about the profitability of the undertaking and capital appreciation Nguyen et al. (2020). Therefore, the main mission of every undertaking should be to harmonize the economic meaning of business with the responsibility for its impacts on the whole society. What becomes evident is the need for transparent communication of this requirement, i.e., reporting to the public. Ioannou \& Serafeim (2017) emphasize the need for transparency in the disclosure of the impact of corporate activities on society, which they clearly see as a commitment to society. Boutin-Dufresne \& Savaria (2004) points out the growing importance of non-financial reporting, which they consider a very important report on sustainability. Jones (2014) describes the period from 2010 onwards as the "Age of Damage", calling for responsible disclosure of non-financial information in connection with financial information. On the other hand, in recent years, there has been a growing interest of users in disclosure of non-financial corporate information, as observed by Haller et al. (2017) and Lončar et al. (2019). Non-financial information contains a wide range of aspects and its impact can therefore be very broad. The fact that there is no uniform definition of the content of non-financial information leads to large differences in its reporting by individual undertakings. One of the most developed methodologies that defines non-financial indicators is the Global Reporting Initiative (GRI STANDARDS). On its basis, the indicators are divided into five main areas: economic, environmental, labour law, social, and human rights. These areas come from the triple bottom line for public sector accounting, which was approved by the UN in 2007 (Plášková \& Ryšánek, 2016).

\section{Literature review}

On 22 October 2014, Directive 2014/95/EU (hereinafter the Directive), which contains non-financial reporting of large undertakings, was adopted by the European Parliament and the Council. For the first time it imposes an obligation on certain large undertakings to report non-financial information. The information must be with a clearly defined structure either in the annual report or in a separate report. This Directive amended the former Directive (Directive 2013/34/EU), which recommended reporting non-financial key performance indicators of the undertaking together with financial indicators. However, the obligation to report this information is imposed only on large public-interest entities, as their activities have significant impacts on society as a whole. The European Union (EU) has long sought to reduce the administrative burden on small and medium-sized undertakings. For this reason, 
these undertakings are excluded from the recommendations and are therefore not required, unlike defined large undertakings, to report non-financial information from 2017. The aim of the European Commission is to strive for a sustainable world economy that combines long-term profitability with social justice and environmental protection. (eur-lex.europa.eu). The Directive is the first instrument to lay down general rules and requirements for the reporting of non-financial information in order to make the reporting of this information uniform and systematic for undertakings within the EU. Some undertakings perceive non-financial reporting as unnecessary and inefficient, which follows from a study by (Sedláček \& Popelková, 2020), who stated that some undertakings are not interested in publishing financial statements, even regardless of regulatory requirements and user needs. In contrast, some undertakings were found to have reported non-financial information even before the adoption of the Directive. These are undertakings that pride themselves on their know-how, popularity with customers, attitude to the environment, etc. According to Zadražilová (2010), economic responsibility is a possible competitive advantage for an undertaking. Weihrich (2013) see non-financial reporting as increasing the undertaking's credibility and transparency as well as building a reputation which leads to a strong market position.

In 2016, Act No. 462/2016 Coll. amending the original Act No. 563/1991 Coll. on Accounting, as amended, was published in the Collection of Laws in Volume 185. This is the measure by which the Directive was implemented in law. Therefore, from 2017, large undertakings in the Czech Republic must report non-financial information in a form defined by the Accounting Act if they are commercial undertakings and public interest entities at the same time and if at the balance sheet date, they exceed the average number of employees of 500.

In contrast to developed European countries, especially Western Europe, nonfinancial reporting does not have a long tradition in the Czech Republic. Nonfinancial reporting has a strong tradition especially in countries with strong capital influence where investment decisions depend on the information published in annual reports Nobes et al. (2012). Undertakings in the Czech Republic do not attach much importance to non-financial reporting, as shown by research Schwarzová (2019). However, Čevela \& Bílková (2016) point out that in recent years there has been an increased interest in disclosure of non-financial information by undertakings in the Czech Republic. A similar topic was also addressed by KPMG (2017), which confirms that significant progress has been made in non-financial reporting in the Czech Republic. It can therefore be further assumed that in the coming years a larger number of undertakings will report non-financial information, and its quality will increase. At the same time, Sedláček (2020) draws attention to a growing trend towards publishing non-financial information by large undertakings in comparison with small and medium-sized undertakings.

\section{Methodology}

One of the aims of this paper is to answer the question of whether there has been a qualitative or quantitative change in the non-financial reporting of enterprises for 
which disclosure is mandatory. It also deals with the answer to the research question whether the size of a company in the category of large companies affects the willingness of companies to report non-financial information.

A comparison of reported non-financial information was made for 2016 and subsequently for 2017 and 2018, i.e., for the years before and after the implementation of the Directive. Based on comparison it was examined whether the legislative measure adopted contributed to higher quality non-financial reporting. The total number of undertakings is 15 . The content analysis of a total of 45 reports for the years 2016, 2017 and 2018, which was performed manually, enabled to assess the approach of the undertakings studied to non-financial reporting. Subsequently, the data were processed using MS Excel. The research was based on indicators which included economic, environmental, labour law, human rights and social areas. Specific non-financial indicators were based on the Global Reporting Initiative (GRI) methodology.

\section{Results}

\section{Impacts of the implementation of the Directive on the quality and quantity of reported non-financial information}

In the Czech Republic starting from 2017, large accounting entities that are commercial undertakings and public interest entities at the same time are required to report non-financial information if at the balance sheet date, they exceed the criterion of an average number of 500 employees during the accounting period. After the exclusion of financial institutions, this obligation applies to a total of 15 undertakings, which must provide non-financial information. This section will examine whether there has been a qualitative or quantitative change in the reporting of non-financial information by these undertakings since 2017 when the Directive came into effect.

The table 1shows the results of the analysis of non-financial information disclosed by all fifteen undertakings in the Czech Republic that have this obligation for 2016, 2017 and 2018. The results for 2017 and 2018 are identical, therefore they are given in one column. Each section of the table focuses on one area of nonfinancial reporting in accordance with the GRI methodology.

The first area is the economic area, which most often includes information about investments and risks. The second most reported indicator is the representation of the state as the owner in the ownership structure. Another reported subject is the environmental area, with the most frequently reported information being total consumption (and possibly sales) of electrical energy or e.g. use of renewable materials in production/operation. The companies do not report at all on potential negative impacts that their business might have on the environment and on the rate of reduction of these impacts. The third area of non-financial reporting is the area of labour law. Most companies report a percentage of persons in governing bodies by sex. This is followed by information on the type and scope of training provided to employees to improve their skills. 
A part of non-financial reporting about the undertaking is also the social area. The undertakings studied here mostly dealt with legal acts of unfair competition.

It should be noted that the implementation of the Directive did not in principle bring about a quantitative or qualitative improvement in reported non-financial indicators, as it follows from the analysis. Only minimal differences were found in the individual areas of non-financial reporting. This situation can be attributed to the fact that even the statutory audit of these undertakings in the field of non-financial information does not order a closer examination of its content, it only requires an auditor's opinion on whether the non-financial information was presented and disclosed. For detailed results and numbers see attached Table 1 below, where there are only criteria that were reported by at least 5 surveyed enterprises in the monitored years. The social area is missing in the table, because in no year at least 5 monitored companies did not show the criteria.

Table 1: Non-financial reporting in the economic, environmental, social area and in the area of labour law

\begin{tabular}{|c|c|c|}
\hline \multirow[t]{2}{*}{ Indicator } & \multicolumn{2}{|c|}{$\begin{array}{l}\text { Number of } \\
\text { reporting } \\
\text { undertakings }\end{array}$} \\
\hline & 2016 & $\begin{array}{l}2017, \\
2018\end{array}$ \\
\hline \multicolumn{3}{|l|}{ Economic area } \\
\hline $\begin{array}{l}\text { Total value received by the undertaking from the state or state } \\
\text { organizations (including e. g. tax reliefs and benefits, } \\
\text { incentives, contributions, grants, etc.) }\end{array}$ & 6 & 6 \\
\hline $\begin{array}{l}\text { Information on whether and to what extent the state is } \\
\text { represented as the owner in the ownership structure of the } \\
\text { undertaking }\end{array}$ & 7 & 7 \\
\hline $\begin{array}{l}\text { Rate and development of significant investments in } \\
\text { infrastructure projects and related services }\end{array}$ & 9 & 10 \\
\hline \multicolumn{3}{|l|}{ Environmental area } \\
\hline Use of non-renewable materials in production / operation & 4 & 5 \\
\hline Use of renewable materials in production / operation & 5 & 5 \\
\hline $\begin{array}{l}\text { Total consumption of fuel from non-renewable resources by } \\
\text { type of fuel }\end{array}$ & 4 & 5 \\
\hline Total consumption of electrical energy & 5 & 6 \\
\hline $\begin{array}{l}\text { Reduction of energy consumption as a direct impact of } \\
\text { energy-saving investigations and initiatives }\end{array}$ & 5 & 6 \\
\hline \multicolumn{3}{|l|}{ Labour law } \\
\hline $\begin{array}{l}\text { Information about the type and scope of training provided to } \\
\text { employees }\end{array}$ & 0 & 7 \\
\hline Percentage of persons in governing bodies by sex & 9 & 9 \\
\hline
\end{tabular}




\begin{tabular}{|l|l|l|}
\hline Percentage of persons in governing bodies by age groups & 5 & 5 \\
\hline
\end{tabular}

Source: The author's own work based on annual or separate reports of the undertaking.

The following criteria were reported by less than 5 companies, therefore they are not included in the table above and are mentioned in the text instead. The average count of companies that reported on the following criteria ranged from 1 to 3 . The criteria from the economic area are Description of risks and opportunities associated with climate change and their classification, Possible impacts of risks and opportunities that would occur if no remedial action was taken, Costs of measures taken in response to these risks/opportunities, Proportion of employees on the minimum wage to all employees, Actual or expected positive or negative impact of these investments on local communities and the economy, Economic development in economically backward areas, Increasing skills and education in a professional group or geographical region, Supporting, enabling or limiting foreign direct investment and Information on whether these investments and services are of a commercial nature or whether they are voluntary or pro bono activities. The change in reporting between 2016 and 2017 occurred only for the criteria: Costs of measures taken in response to these risks/opportunities, Actual or expected positive or negative impact of these investments on local communities and the economy, Increasing skills and education in a professional group or geographical region, Information on whether these investments and services are of a commercial nature or whether they are voluntary or pro bono activities and in all cases, the change was by one company.

From the environmental area the criteria are Recycled input materials used for the production of primary products and services, Total consumption of fuel from renewable resources by type of fuel, Total consumption of energy for cooling and air conditioning, Type of energy whose consumption was reduced, Reduction of energy intensity of products and services for the period studied, Total volume of water consumed from various sources, Total volume of water recycled and reused by the undertaking, Significant direct and indirect impacts of the undertaking on biodiversity, Size and location of all protected or restored environments, Information on whether there is a partnership with third parties concerning the protection or restoration of the environment, Direct and indirect greenhouse gas emissions, Information about which greenhouse gases $(\mathrm{CO} 2, \mathrm{CH} 4$, etc.) were emitted, Total number of significant non-monetary sanctions and the monetary value of penalties, Negative environmental impacts of the transport of products and other goods and material and the transport of employees, Total expenditure on waste disposal, emissions management and remediation measures. The change in reporting between 2016 and 2017 occurred only for the following criteria: Recycled input materials used for the production of primary products and services, Total consumption of energy for cooling and air conditioning, Type of energy whose consumption was reduced, Reduction of energy intensity of products and services for the period studied, Significant direct and indirect impacts of the undertaking on biodiversity, Size and location of all protected or restored environments, Negative environmental 
impacts of the transport of products and other goods and material and the transport of employees and always just by one company.

Regarding labour law area, the criteria are Total number and proportion of newly hired employees by age and sex, Benefits provided as standard to full-time employees that are not provided to part-time employees or employees on other types of contracts, Type of workplace accidents, percentage of accidents, proportion of occupational diseases, missed days and fatal work-related accidents, Average number of training hours that employees participated in, Percentage of persons as employees by sex. A change by one company occurred in reporting of criterion Average number of training hours that employees participated in.

From the social area the criteria are Undertakings with significant actual or potential negative impact on local communities, Training of and communication of valid anti-corruption policies to employees, Total number and nature of confirmed cases of corrupt practices, Lawsuits against the undertaking or its employees on suspicion of corrupt practices, Number of legal acts in the field of unfair competition, cartel agreements and monopolistic practices, Main results of completed legal acts in this area, Information on infringements that led to the imposition of fines and sanctions, Number of complaints concerning the influence on the undertaking filed through formal channels during the accounting period. A change by two companies occurred in reporting of the following criteria: Training of and communication of valid anti-corruption policies to managing authorities, Total number and nature of confirmed cases of corrupt practices, Lawsuits against the undertaking or its employees on suspicion of corrupt practices, Significant fines and non-monetary sanctions. A change by one company occurred in reporting of the following criteria: Undertakings with significant actual or potential negative impact on local communities, Lawsuits against the undertaking or its employees on suspicion of corrupt practices, Number of legal acts in the field of unfair competition, cartel agreements and monopolistic practices, Main results of completed legal acts in this area, Information on infringements that led to the imposition of fines and sanctions.

\section{Non-financial reporting with respect to the size of the undertaking}

This part of the paper gives us an answer to the basic research question whether the size of the undertaking within the category of large undertakings affects the willingness of undertakings to report non-financial information. The size of the undertaking is determined by the size of turnover. A study was made of undertakings which are classified as large accounting entities and at the same time have more than 500 employees. The undertakings meeting these criteria were obtained from the Orbis database for 2018. A total of 568 undertakings were examined. Finally, a hypothesis was formulated to find an answer to the basic research question.

A prerequisite for the use of the Pearson chi-square test is that at least $80 \%$ of the expected frequencies acquire values higher than 5. For this reason, pivot table was first compiled. Furthermore, the dependencies between selected quantities on the basis of the statistical test of chi-square independence will be tested. In the 
following pivot table, the size of the undertaking is determined by the size of turnover both in absolute and relative terms.

$\mathrm{H} 1_{0}$ : There is no relationship between the non-financial reporting of the undertaking and the size of its turnover.

The table below examines the relationship between these quantities.

Table 2: Relationship between non-financial reporting (NFR) and the size of the undertaking with regard to its turnover in millions of EUR.

\begin{tabular}{|l|c|c|c|c|c|c|}
\hline \multirow{2}{*}{$\begin{array}{l}\text { Turnover } \\
\text { in } \\
\text { millions } \\
\text { of EUR }\end{array}$} & \multicolumn{2}{|c|}{ NO } & \multicolumn{2}{c|}{ YES } & \multicolumn{2}{c|}{ Total } \\
\cline { 2 - 7 } & Absolute & $\%$ & Absolute & $\%$ & Absolute & $\%$ \\
\hline$<100$ & 170 & 73 & 62 & 27 & 232 & 100 \\
\hline $100-200$ & 93 & 60 & 61 & 40 & 154 & 100 \\
\hline $200-300$ & 34 & 50 & 34 & 50 & 68 & 100 \\
\hline $300-400$ & 14 & 44 & 18 & 56 & 32 & 100 \\
\hline $400-600$ & 10 & 36 & 18 & 64 & 28 & 100 \\
\hline $600<$ & 5 & 9 & 49 & 91 & 54 & 100 \\
\hline TOTAL & $\mathbf{3 2 6}$ & $\mathbf{5 7}$ & $\mathbf{2 4 2}$ & $\mathbf{4 3}$ & $\mathbf{5 6 8}$ & $\mathbf{1 0 0}$ \\
\hline
\end{tabular}

Source: The author's own work.

The table 3 shows the result based on statistical testing using the Pearson chisquare test to determine the relationship between NFR and the size of the undertaking with respect to its turnover.

Table 3: Results of statistical testing

\begin{tabular}{|l|c|c|c|c|}
\hline $\begin{array}{l}\text { Undertaking } \\
\text { size by }\end{array}$ & $\begin{array}{c}\text { Degrees of } \\
\text { freedom }\end{array}$ & p-critical & p-statistic & p-value \\
\hline $\begin{array}{l}\text { Size of } \\
\text { turnover }\end{array}$ & 5 & 11.1 & 328.99 & $\begin{array}{c}5.22155 \mathrm{E}- \\
14\end{array}$ \\
\hline
\end{tabular}

Source: The author's own work.

With regard to the answer to the basic research question, the hypothesis was evaluated, namely there is no relationship between the willingness to report nonfinancial information and the size of the undertaking with regard to the size of turnover. The testing resulted in the rejection of the null hypothesis that there is no relationship between non-financial reporting and the size of the undertaking. It can therefore be confirmed that there is a significant relationship between the willingness to report non-financial information with regard to its size. Empirical data confirmed the reluctance of the remaining undertakings studied to report this information. 


\section{Conclusion}

The paper examined the issue of disclosure of non-financial information in relation to its quantity and quality. The first part of the paper dealt with undertakings that are public interest entities and non-financial reporting is mandatory for them. The study was based on content analysis of annual reports of Czech public interest entities or separate reports on non-financial information in 2016, 2017 and 2018 and their subsequent comparison. The original assumption that there was a qualitative and quantitative increase in reported indicators, especially in 2017, i.e., after the implementation of the Directive, was not confirmed. With regard to the quality and quantity of reported information, there was only a minimal difference between individual years. This can be attributed to the fact that the Directive defines the requirements for non-financial reporting rather generally without further specifications. Despite the obligation to report non-financial information, the method and form of reporting are not specified. The consequence is that even undertakings, for which non-financial reporting is mandatory, report in different quantities and qualities. However, the analysis showed that in most cases non-financial reporting serves primarily as a tool for presenting successes and positive activities of the undertaking.

The second part of the paper examined undertakings that are classified as large accounting entities and also have more than 500 employees. A total of 568 undertakings were examined, and it was found that only $43 \%$ of them report non-financial information. In this part of the paper, the aim was to answer the research question whether the size of turnover of the undertaking within the category of large undertakings affects the willingness to report non-financial information.

The results show that it would be appropriate to create rules for reporting nonfinancial information, in particular with regard to its structure and content. It is suggested to prepare reports according to the GRI instructions and framework. This would lead to higher quality reporting of non-financial information and increased transparency and competitiveness of Czech undertakings and convergence with other developed countries.

\section{References}

1. Boutin-Dufresne, F., \& Savaria, P. (2004). Corporate social responsibility and financial risk. The Journal of investing, 13(1), 57-66. https://doi.org/10.1007/s10551-007-9609-8

2. Čevela, D., \& Bilkova, K. (2016). Reporting on selected aspects of the corporate social responsibility in the Czech Republic. Ad Alta: Journal of Interdisciplinary Research, 6(2).

3. Česko, (1991). Zákon č. 563/1991 Sb., o účetnictví, ve znění pozdějších předpisů. In: Sbírka zákonů České republiky. From https://apps.odok.cz/kpl-detail?pid=KORN9N6EU93J.

4. Česko, (2016). Zákon č. 462/2016 Sb. Zákon, kterým se mění zákon č. 563/1991 Sb., o účetnictví, ve znění pozdějších předpisů. [online]. Sbírka zákonů, 2016. From https://www.epravo.cz/_dataPublic/sbirky/2016/sb0185-2016.pdf

5. EU, (2013). Směrnice Evropského parlamentu a Rady 2013/34/EU o ročních účetních závěrkách, konsolidovaných účetních závěrkách a souvisejících zprávách některých forem podniků, o změně směrnice Evropského parlamentu a Rady 2006/43/ES a o zrušení směrnic 
Rady 78/660/EHS a 83/349/EHS from June 29, 2013. From https://eur-lex.europa.eu/legalcontent/CS/TXT/?uri=celex\%3A32013L0034.

6. Haller, A., Link, M., \& Groß, T. (2017). The term 'non-financial information'-a semantic analysis of a key feature of current and future corporate reporting. Accounting in Europe, 14(3), 407-429. https://doi.org/10.1080/17449480.2017.1374548

7. Ioannou, I., \& Serafeim, G. (2017). The consequences of mandatory corporate sustainability reporting. Harvard Business School research working paper, From https://papers.ssrn.com/sol3/papers.cfm?abstract_id=1799589

8. Jones, D. (2014). Společensky odpovědné chování se firmám vyplácí. Management Press.

9. KPMG. (2017). The road ahead-The KPMG Survey of Corporate Responsibility Reporting 2017. KPMG International.

10. Lončar, D., Paunković, J., Jovanović, V., \& Krstić, V. (2019). Environmental and social responsibility of companies cross EU countries-Panel data analysis. Science of the total environment, 657, 287-296. https://doi.org/10.1016/j.scitotenv.2018.11.482

11. Nobes, C., Parker, RB, \& Parker, RH (2012). Srovnávací mezinárodní účetnictví . Pearson Education.

12. Nguyen, THH, Ntim, CG a Malagila, JK (2020). Ženy ve správních radách společností a finanční a nefinanční výkony společností: Systematický přehled literatury a budoucí výzkumná agenda. International Review of Financial Analysis, 101554. https://doi.org/10.1016/j.irfa.2020.101554

13. Plášková, A., \& Ryšánek, P. (2013). Společenská odpovědnost (CSR): hodnocení CSR firem v programu Národní ceny ČR za společenskou odpovědnost:[podnikatelský sektor]. Národní informační stř̌edisko podpory kvality.

14. Pramanik, A. K., Shil, N. C., \& Das, B. (2008). Corporate environmental reporting: An emerging issue in the corporate world. International Journal of Business and management, 3(12), 146-154. https://doi.org/10.34104/cjbis.020.045053

15. Schwarzová, A. Vykazování a řízení nefinančních informací v podnicích veřejného zájmu v ČR. [online]. Vysoká škola ekonomická v Praze, Fakulta financí a účetnictví, Katedra manažerského účetnictví. Diplomová práce, 2019. From https://vskp.vse.cz/78293_vykazovani_arizeni_nefinancnich_informaci_subjekty_verejneho _zajmu_vcr

16. Sedláček, J., \& Popelková, V. (2020). Non-financial information and their reportingevidence of small and medium-sized enterprises and large corporations on the Czech capital market. National Accounting Review, 2(2), 204. https://doi.org/10.3934/NAR.2020012

17. Sedláček, J. (2020). Nefinanční výkaznictví průmyslových podniků - česká př́ípadová studie. Acta Universitatis Agriculturae et Silviculturae Mendelianae Brunensis , 68 (3), 625-636. https://doi.org/10.11118/actaun202068030625

18. Směrnice evropského parlamentu a rady 2014/95/EU. Eur-lex.europa.eu. [online]. [cit. 3. 8. 2020]. From https://eur-lex.europa.eu/legalcontent/CS/TXT/HTML/?uri=CELEX:32014L0095\&from=EN

19. Weihrich, H. (2013). Management: A global, innovative, and entrepreneurial perspective. Tata McGraw-Hill Education.

20. Zadražilová, D. (2010): Společenská odpovědnost podniku. Transparentnost a etika podnikání. 1. vyd. 